\title{
JUDICIALIZATION OF ADMINISTRATIVE LAW: THE TRIAL-TYPE HEARING AND THE CHANGING STATUS OF THE HEARING OFFICER
}

\author{
FREDERICK DAVIS*
}

The judicialization of the administrative process, a phenomenon largely taken for granted by both lawyers and the general public in contemporary America, is probably one of the most mysterious, yet significant, features of American government. It is significant because of its increasingly recognized cost and because of the dominant role which it assigns to lawyers. ${ }^{1}$ It is mysterious because of the fragile constitutional underpinnings upon which the judicialization was originally based, ${ }^{2}$ and because of its remarkable endurance and growth. ${ }^{3}$

* Hinton Professor of Law, University of Missouri-Columbia. A.B. 1948, Yale University; J.D. with specialization in international affairs, 1953, Cornell University; LL.M. (honors) 1954, Victoria University of Wellington (N.Z.). Member, New York and Missouri Bars.

THE FOLLOWING CITATIONS WILL BE USED IN THIS ARTICLE:

Commission on Organization of the Executive Branch of the Government, Legal Services and Procedure (1955)[hereinafter cited as HoOver Commission RePORT];

Commission on Organization of the Executive Branch of the Government, Task Force Report on Legal Services and Procedure (1955)[hereinafter cited as Hoover CoMMISSION TASK FORCE REPORT];

Mashaw, The Supreme Court's Due Process Calculus for Administrative Adjudication in Mathews v. Eldridge: Three Factors in Search of a Theory of Value, 44 U.CHI. L. REv. 28 (1976) [hereinafter cited as Mashaw].

1. See J. Auerbach, Unequal Justice $191-230$ (1976); Auerbach, A Plague of Lawyers, HARPER'S, October 1976, at 37.

2. Just why the ultimate availability of judicial relief against allegedly illegal administrative action does not satisfy due process requirements has never been made quite clear, despite the elaborate explanations generated by such decisions as Goldberg v. Kelly, 397 U.S. 254 (1970). A wrong turn may have been taken in the little-noticed case of Goldsmith v. Board of Tax Appeals, 270 U.S. 117 (1926), in which the petitioner had been refused admission to practice before the Board. He sought mandamus, alleging satisfaction of Board requirements for admission. The Board filed an answer asserting facts concerning petitioner's reputation which appeared legally to justify their refusal of admission. The petitioner did not deny those facts, but asserted that they were unreliable "hearsay." The lower court denied mandamus on the ground that the evidentiary hearings did not indicate illegal exercise of discretion by the Board. Goldsmith v. Board of Tax Appeals, 4 F.2d 422 (D.C. Cir. 1925). The Supreme Court held that the discretionary power to deny admission meant "a discretion to be exercised after fair investigation, with such a notice, hearing and opportunity to answer for the applicant as would constitute due process." 270 U.S. at 123. The Court then pointed out that the petitioner had not demanded the procedure which the Court, apparently for the first time, was declaring applicable through a highly artificial interpretation of the meaning of the word "discretion," and that mandamus was therefore inappropriate. Id. The decision was presumably grounded on petitioner's failure to exhaust his administrative remedy, although the Court did not advert to that shortcoming in those precise terms.

3. The adoption of a federal Administrative Procedure Act in 1946 was a major movement 
Some understanding of this judicialization process is critical as legislatures and the legal community contemplate future innovations in administrative procedure. In order to determine precisely when hearings are necessary, for example, one must first undertake a comprehensive examination of the reasons for which hearings have been required in various situations in the past. Similarly, an understanding of when hearings are necessary is an important prerequisite to determining what kind of hearing is needed and what qualifications a presiding officer must have in order to realize the goals of the hearing process. The judicialization process, therefore, deserves a much more comprehensive analytical and historical description than has yet been undertaken. The purpose of this Article is to begin that effort by focusing on three aspects of the phenomenon: first, the development of the various conceptions of the hearing officer which have evolved in response to the need for a supervising authority at trial-type administrative hearings; second, the multiple considerations which may combine to require a trialtype administrative hearing; and third, the changes signaled by the enhanced status which is being given to presiding officers and their adjudicative decisions.

\section{EVOLUTION OF THE ADMINISTRATIYe LAW JUDGE}

Almost all agencies and departments of government have both management-level and subordinate employees. Before judicialization of the administrative process began, the legal implications raised by the use of subordinates to perform various investigative or evaluational functions were not serious. ${ }^{4}$ As judicialization began, however, judges increasingly took the position that certain types of governmental actions would not be sustained unless the agency itself had extended the adversely affected party procedural protections akin to those commonly associated with the judicial process-basically, notice and an opportunity to be heard. ${ }^{5}$ Since these procedures were deemed to be constitutionally required, the agency action, however meritorious and substantively within its powers, would be ruled invalid by a judge if requisite procedural protections had not been extended by the agency.

The types of governmental actions which were initially subject to these procedural requirements typically involved controversies which turned on

in the direction of judicialization. See Schotland, After 25 Years: We Come to Praise the APA and Not to Bury It, 24 AD. L. REv. 261, 264 (1972); Williams, Fifty Years of the Law of the Federal Administrative Agencies-and Beyond, 29 FED. B.J. 267, 268 (1970).

4. The evolution of the process by which subordinate officials conduct hearings on behalf of agency members is succinctly described in W. GELLHORN \& C. BYSE, ADMINISTRATIVE LAW: CASES AND COMMENTS 1043-45 (6th ed. 1974).

5. See, e.g., Goldsmith v. Board of Tax Appeals, 270 U.S. 117, 123 (1926), discussed in note 2 supra. For an excellent, concise analysis and description of the decisions through which the Supreme Court has accomplished a judicialization of administrative law, see Mashaw 28-29. 
"circumstantial" or "adjudicative" facts: for example, whether the shape of a parcel of real estate justified the application of a purely frontal footage formula in making assessments for improvements, ${ }^{7}$ or whether an applicant was eligible to practice before the United States Board of Tax Appeals. ${ }^{8}$ Over the years, however, the courts have steadily expanded the spectrum of individual interests that may not be affected or adjusted without an administrative hearing incorporating at least some elements of the judicial model. ${ }^{9}$ Thus, the dismissal or suspension of a public school student, ${ }^{10}$ or the termination of certain types of governmental benefits, ${ }^{11}$ have traditionally failed to receive judicial approval unless prior notice and an opportunity for an administrative hearing are extended to the affected person or persons. ${ }^{12}$ The judicial imposition of hearing requirements on administrative agencies has been paralleled by legislation which also mandates administrative hearings. ${ }^{13}$

Responding to both legislative and judicial commands that some sort of quasi-judicial procedure precede or accompany certain administrative actions, the agencies fell into the practice of assigning the hearing function (as they had become accustomed to assigning various other functions) to subordinate employees or officials. ${ }^{14}$ The responsibility for deciding who would preside over the proceedings at which evidence would be taken, testimony heard and (perhaps) a transcript made, was not exercised with any great amount of care or concern. The persons so chosen might or might not have been lawyers; they might or might not have been independent of peer or

6. A useful discussion of the concept of adjudicative fact and the early origins of the principle requiring a trial for disputed adjudicative facts is presented in $\mathrm{K}$. DAVIS, ADMINISTRATIVE LAW TEXT $\$ 7.03$, at 161-62 (3d ed. 1972).

7. See Londoner v. Denver, 210 U.S. 373, 385 (1908).

8. See Goldsmith v. Board of Tax Appeals, 270 U.S. 117 (1926).

9. See Mashaw $28 \mathrm{n} .1$ (and cases cited therein). There is evidence that the expansionist tide in the due process area has begun to ebb. See the authorities cited in note 42 infra.

10. Goss v. Lopez, 419 U.S. 565 (1975); Horowitz v. Board of Curators, 538 F.2d 1317 (8th Cir. 1976) (expulsion from medical school), petition for cert. granted, 97 S.Ct. 1642 (1977); Dixon v. Alabama State Bd. of Educ., 294 F.2d 150 (5th Cir.), cert. denied, 368 U.S. 930 (1961).

11. Wheeler v. Montgomery, 397 U.S. 280 (1970) (old age benefits); Goldberg v. Kelly, 397 U.S. 254 (1970) (welfare benefits). But prior notice and an evidentiary hearing need not be given before administrative termination of social security disability benefits when an evidentiary hearing is provided before final denial of the disability claim. Mathews v. Eldridge, 424 U.S. 319 (1976). See also Mashaw 29 n.5 (suggesting that the Court may be shifting ground as regards the applicability of the due process clause).

12. See generally Friendly, "Some Kind of Hearing," 123 U. PA. L. REv. 1267 (1975). But see Bishop v. Wood, 426 U.S. 341 (1976), and note 42 infra and accompanying text.

13. One of the first such pieces of legislation was a federal statute in 1906 which authorized the Interstate Commerce Commission to employ "special agents or examiners who shall have power to administer oaths, examine witnesses, and receive evidence." Act of June 29, 1906, ch. $3591, \S 7,34$ Stat. 595 , discussed in 2 K. Davis. Administrative LAW TrEatise $\$ 10.01$ (1958).

14. See generally B. SChWARTZ, ADMINISTRATIVE LAW § 101 (1976). See also note 4 supra. 
staff influence, and they might or might not have been previously involved in investigative or prosecutorial phases of the proceeding. The sole function of the early presiding officer was simply to monitor or supervise that phase of the proceeding wherein the data, information and arguments which the agency had been told it was required to consider were to be adduced.

The view which validated such a cavalier attitude toward the status and manner of appointment of the persons presiding at administrative hearings was that the function of such a presiding officer was almost totally ministerial and in no way influenced the final disposition of the matter at issue. The assumption was that the presiding officer merely monitored the various materials submitted by interested parties, organized them, and submitted the resulting "record" to the agency heads whom the legislature had charged with the responsibility for action or nonaction. ${ }^{15}$

Beginning about 1917, the Interstate Commerce Commission introduced the system of having its presiding officers (called "examiners") file proposed reports. ${ }^{16}$ This meant that, in addition to monitoring and processing materials offered by the interested parties, the examiner was to supply his own appraisal, summary, or recommended disposition. ${ }^{17}$ Whether or not it was fully perceived by the initiators of this new system, an important threshold had been crossed: instead of assuming the passive role of receiving and organizing submissions for appraisal by the responsible authority, the presiding officer was assigned the active role of making a significant contribution to the decisional process in the form of his own summaries or recommendations.

Alternatives to the practice of having administrative matters initially heard and processed by a presiding officer were explored episodically by various federal agencies prior to $1940,{ }^{18}$ but in 1941 the Attorney General's Committee on Administrative Procedure endorsed the single examiner

15. Committee on Administrative Procedure, Administrative Procedure in GovernMENT Agencies, S. Doc. No. 8, 77th Cong., 1st Sess. 44-45 (1941). In contrast to the subsequent enhancement of the hearing officer's status in the federal system, many state agencies' procedures continue to reflect a "ministerial" conception of the officer's functions. See notes 22-24 infra and accompanying text.

16. See $2 \mathrm{~K}$. DAvis, supra note $13, \$ 10.01$ at 2 .

17. Although largely mooted at the federal level by a specific provision of the Administrative Procedure Act, 5 U.S.C. \$ 557(c) (1970) ("All decisions, including initial, recommended, and tentative decisions are a part of the record . . .'), the question whether the independently generated report of the presiding officer should be available to all parties has been a matter of lively controversy at the state level. See, e.g. , Des Plaines Currency Exchange v. Knight, 29 Ill. 2d 244, 194 N.E.2d 89 (1963), cert. denied, 376 U.S. 969 (1964); Mazza v. Cavicchia, 15 N.J. 498, 105 A.2d 545 (1954); See also Davis, The Missouri Public Service Commission, 42 U. Mo. KAN. City L. REV. 279, 287 (1974).

18. For a description of the Federal Communication Commission's utilization of what may be called a "committee" for the preparation of its original decision, see $2 \mathrm{~K}$. DAvis, supra note $13, \S 10.01$, at 3 . 
theory with such vigor that this approach to the problem can easily be said to have carried the day. ${ }^{19}$ Although the recommendations of the Committee were not enacted into law until the passage of the Administrative Procedure Act in $1946,{ }^{20}$ the concept of an independent presiding officer-now titled an Administrative Law Judge (ALJ)-has become a firmly established tradition within the federal administrative establishment. ${ }^{21}$

\section{State Law Developments}

Developments at the state level have been conspicuously inconsistent. In contrast to the increased responsibilities and qualifications of federal Administrative Law Judges, many state statutes continue to reflect the early view of the presiding officer as a functionary. ${ }^{22}$ In Missouri, for example, responsibility for presiding at initial hearings in workmen's compensation cases is assigned to agency-appointed employees ${ }^{23}$ whose findings are accorded little significance on judicial review. ${ }^{24}$ Neither the original Model State Administrative Procedure $\mathrm{Act}^{25}$ nor the more recent revised version of the $\mathrm{Act}^{26}$ provides for the recognition and appointment of independent examiners with minimum qualifications for presiding or conducting administrative hearings. North Carolina's recently enacted Administrative Procedure Act seems to follow this trend by permitting hearings to be conducted by officers appointed by the agency while apparently imposing no restrictions on the discretion to appoint. ${ }^{27}$

Other states, such as New York ${ }^{28}$ and Iowa, ${ }^{29}$ adhere more closely to the federal model and provide an independent certification process followed

19. Committee on Administrative Procedure, supra note 15 , at $45-46$.

20. Act of June 11, 1946, ch. 324,60 Stat. 237 (codified as amended in 5 U.S.C. $\$ \$ 551-559$, $701-706,1305,3105,3344,5362,7521$ (1970)).

21. Examiners satisfying and appointed pursuant to the requirements of the Administrative Procedure Act were retitled as "Administrative Law Judges" in 1972. See 5 C.F.R. \$ 930.203a (1976). For a useful description of the ALJ, see B. SchwARTz, supra note 14, § 103.

22. See note 15 supra and accompanying text.

23. See MO. ANN. STAT. \& 287.610 (Vernon 1965).

24. See Todd v. Goostree, 493 S.W.2d 411 (Mo. App. 1973); Lynn v. Lloyd A. Lynn, Inc., 493 S.W.2d 363 (Mo. App. 1973).

25. The Model Act may be found in 9C UNIForm LAws ANNOTATEd 174-85 (1957).

26. The revised Model Act is set forth in 13 UNIFORM LAwS ANNOTATED 245-91 (Master ed., Supp. 1977).

27. See N.C. GEN. STAT. § 150A-33 (Supp. 1975); Daye, North Carolina's New Administrative Procedure Act: An Interpretative Analysis, 53 N.C.L. REv. 833, 885-87 (1975).

28. The New York Administrative Procedure.Act apparently makes no independent provision for the certification of presiding officers at administrative hearings, although it deals specifically with their powers. N.Y. AdMINISTRATIVe Procedure ACT \$§ 303, 304 (56A McKinney Pamph. 1976). The Civil Service Law, however, provides for examination and classification of categories of employees, and it is apparently through this mechanism that a system similar to the federal system is implemented. N.Y. Crv. SERv. LAw $\S 97$ (McKinney 1973).

29. IowA CODE ANN. § 17A.11(2) (West Supp. 1976). 
by assignment of those certified to particular agencies. California probably goes the farthest by establishing an Office of Administrative Hearings consisting of about twenty hearing officers and other suitable staff. ${ }^{30}$ Unless exempted by statute, agencies which must conduct trial-type hearings under the California Administrative Procedure Act are required to use hearing officers supplied by the Office of Administrative Hearings. The Office is also free to contract with other agencies which hold trial-type hearings to provide hearing officers to such agencies for that purpose. ${ }^{31}$ The significant aspect of the California approach, however, is that no hearing officer is assigned to any particular agency. It is in this respect that the California system differs most markedly from the federal model.

Florida has modeled its new system after that of California, with a few modifications. The most interesting difference between the two acts is Florida's provision for the appointment of an uncertified hearing officer in the event that a certified hearing officer is unavailable. Such a person must come from the staff of an agency other than the one for which the hearing is to be conducted. ${ }^{32}$

The present system in Missouri might best be described as a compromise between the traditional systems and that innovated by California. Most of the non-licensing agencies which are required by law to conduct hearings in various specified circumstances must do so in compliance with the requirements of the Missouri Administrative Procedure Act, ${ }^{33}$ and they are granted discretion to conduct such hearings through the use of hearing officers or examiners. ${ }^{34}$ The law imposes no explicit limitations on the qualifications such officers or examiners must exhibit or on the method by which they are selected. With respect to most licensing agencies, however, hearings are conducted by a unique institution known as the Administrative Hearing Commission which, at present, consists of only one Commissioner. ${ }^{35}$ The Commissioner must satisfy statutorily imposed qualifications. $\mathrm{He}$ is appointed by the governor rather than the particular agency or agencies

30. CAL. Gov'T CODE $\$ \S 11370-11370.5$ (West 1966); id. $\S 11512$ (Supp. 1977); Coan, Operational Aspects of a Central Hearing Examiners Pool: California's Experiences, 3 FLA. ST. U.L. REV. 86 (1975).

31. Coan, supra note 30 , at 87 .

32. FLA. Stat. ANN $\S 120.65$ (West Supp. 1977). For a comprehensive, analytical and illuminating description and explanation of the innovative Florida Act, see Levinson, The Florida Administrative Procedure Act: 1974 Revision and 1975 Amendments, 29 U. MIAMI L. REv. 617 (1975).

33. MO. ANN. STat. $\$ 536.010(2)$ (Vernon Supp. 1977).

34. Although the Missouri Administrative Procedure Act makes no provision for "hearing officers," the practice of delegating the responsibility for conducting hearings in contested cases to a subordinate officer is widespread. See David, supra note 17, at 286.

35. Mo. AnN. Stat. \& 161.252 (Vernon Supp. 1977). 
he serves; thus, unlike the federal $\mathrm{ALJ},{ }^{36}$ the Commissioner has no ties to any particular agency. ${ }^{37}$

\section{When Should A Trial-Type Hearing Be Required?}

A subject which deserves far more attention than it has yet been given by administrative law scholars concerns the criteria which determine when an administrative hearing is required and the procedural amenities which must be observed at such a hearing. Since the services of an independent presiding officer are normally needed only in the event of a trial-type hearing, a brief review of the circumstances which may call for such a hearing is appropriate.

A categorical analysis of the question indicates at least four situations which may require an administrative hearing: (1) procedural due process requirements of either a state or the federal constitution; ${ }^{38}$ (2) a general legislative requirement imposed by the provisions of an administrative procedure act; ${ }^{39}$ (3) a specific requirement imposed by the legislature when it created the agency in question; 40 and (4) a "self-certification" process by which one of the parties alleges that despite the form of the proceeding, there are issues of circumstantial or adjudicative fact which require the grant of an administrative hearing. ${ }^{41}$ While the distinctions may become blurred as a result of several recent Supreme Court cases which give great weight to statutory procedures in determining constitutional due process interests, ${ }^{42}$ it is nonetheless important to keep in mind that any of these four types of requirements may be used to support a right to an administrative hearing in a particular case.

36. See generally Karl Stecher, 11 Ad.L.2d 868 (Civil Serv. Comm'n 1961).

37. MO. ANN. STAT. $\$ 161.252$ (Vernon Supp. 1977). For a comprehensive discussion of the Missouri Administrative Commission see Special Project-Fair Treatment for the Licensed Professional: The Missouri Administrative Hearing Commission, 37 Mo. L. Rev. 410 (1972).

38. See generally Mashaw; Comment, Entitlement, Enjoyment, and Due Process of Law, 1974 DUKE L.J. 89.

39. E.g., 5 U.S.C. $\$$ 554, 556 (1970); Model State Administrative Procedure ACt $\S \S$ 1(3), 8 (1946); Model State Administrative Procedure ACt Revised \$§ 1(2), 9 (1961).

40. E.g., 21 U.S.C. $\S \S 371-377$ (1970); 41 U.S.C. $\$ 43 a(b)$ (1970). See generally Hamilton, Procedures for the Adoption of Rules of General Applicability: The Need for Procedural Innovation in Administrative Rulemaking, 60 CALIF. L. REV. 1276 (1972).

41. E.g., FLA. Stat. ANN. $\$ 120.57$ (West Supp. 1977). For a full discussion of the so-called "self-certification" procedure see Levinson, supra note 32, at 658-59.

42. See Codd v. Velger, 97 S.Ct. 882 (1970); Bishop v. Wood, 426 U.S. 34I (1976); Paul v. Davis, 424 U.S. 693 (1976); Board of Regents v. Roth, 408 U.S. 564 (1972); Rabin, Job Security and Due Process: Monitoring Administrative Discretion Through a Reasons Requirement, $44 \mathrm{U}$. CHI. L. Rev. 60 (1976); Note, Democratic Due Process: Administrative Procedure After Bishop v. Wood, 1977 DUKE L.J. 453 . To the extent that the trend suggested by these authorities continues to dominate future analyses of the right to be heard, the suggestion put forward in this Article that the legislature must balance the factors and policies which underlie hearing requirements more carefully and explicitly takes on added force. Such legislative judgments may fully control due process requirements in the future. 
Where they have found a hearing constitutionally required, the courts have traditionally considered at least four factors in determining what elements of a trial-type proceeding must be employed by the administrative agency. The courts have examined: (1) the "value" of the aggrieved person's interest; ${ }^{43}$ (2) the relative selectivity of the administrative action, i.e., the degree to which it affects this person but not others similarly situated or in the same class; ${ }^{44}$ (3) the effect of a hearing requirement on the capacity of the administrative program to attain its goals; ${ }^{45}$ and (4) the extent and directness of governmental involvement in the activity affecting those who seek a hearing. ${ }^{46}$ Beyond that it is difficult to go. It is often impossible to predict whether a particular component of administrative due process will be required in any particular situation. The ad hoc approach which has been taken by the courts ${ }^{47}$ is not very helpful in deciding, for example, whether, in a situation where a hearing is clearly called for, the aggrieved person is entitled to representation by counsel (whether he can pay for it or not). Nor does it resolve the question whether he should receive the protection of a presiding officer who has not participated in any of the prosecutorial or investigative phases of the case..$^{48}$

What the developing case law does, though, is to provide a framework for making rational judgments. While it does not offer the kind of precision which the language of an administrative procedure act might provide, ${ }^{49}$ the

43. See Mashaw 28-30; Stewart, The Reformation of American Administrative Law, 88 HARV. L. REV. 1669, 1717-22 (1975).

44. See, e.g., United States v. Florida E. Coast Ry., 410 U.S. 224, $245-46$ (1973); BiMetallic Investment Co. v. State Bd. of Equalization, 239 U.S. 441 (1915).

45. See Goss v. Lopez, 419 U.S. 565, 580-82 (1975). In Goss, even the majority agreed that where the value of the governmental interest was sufficiently intense, the procedural due process requirements might yield. "Students whose presence poses a continuing danger to persons or property . . . may be immediately removed from school." Id. at 582. See also Baxter v. Palmigiano, 425 U.S. 308, 320-23 (1976); Wolff v. McDonnell, 418 U.S. 539, 566-70 (1974).

46. See Hahn v. Gottlieb, 430 F.2d 1243, 1246-49 (1st Cir. 1970) (governmental involvement in housing subsidy program insufficiently direct to justify imposition of trial-type hearing prior to rent increase).

47. See, e.g., Dixon v. Alabama State Bd. of Educ., 294 F.2d 150, 158 (5th Cir.), cert. denied, 368 U.S. 930 (1961): "The nature of the hearing should vary depending upon the circumstances of the particular case." Language indicating that the procedures applicable to the administrative hearing will vary with the many factors involved in the dispute is common to almost every case contributing to the "due process explosion" that followed the decision in Goldberg v. Kelly, 397 U.S. 254 (1970). See, e.g., Mathews v. Eldridge, 424 U.S. 319, 332-35 (1975). The Mathews decision is criticized in Mashaw.

48. For a discussion of the constitutional requirement of an impartial presiding officer see Davis, Withrow v. Larkin and the "Separation of Functions" Concept in State Administrative Proceedings, 27 AD. L. REv. 407 (1975); Friendly, supra note 12, at 1279-80.

49. The Supreme Court has acknowledged that judicial pronouncements in this area lave occasionally been less than illuminating:

While the line dividing them may not always be a bright one, these decisions represent a recognized distinction in administrative law between proceedings for the 
case law is at least pragmatic in its attempt to balance conflicting policy objectives such as fairness, accuracy, efficiency and legitimacy in fashioning procedural requirements. To the extent that the judiciary is not the proper forum for establishing general procedural requirements which can be applied in every situation, legislation must reflect these various concerns.

Regrettably, draftsmen have made little effort to incorporate the insights of the judicial experience into statutory procedures. The formulae employed by the leading statutes-the federal Administrative Procedure Act, ${ }^{50}$ the Model State Administrative Procedure Act $^{51}$ and the revised Model State Administrative Procedure Act ${ }^{52}$ - to identify when a particular administrative proceeding requires a trial-type hearing are uniformly unsatisfactory. Instead of addressing themselves to the actual circumstances which may, in the interests of accuracy and acceptability, justify a sacrifice of efficiency through the imposition of a trial-type hearing, these statutes effectively sidestep the issue by providing for a trial-type hearing only where a "hearing" may be otherwise required by "law," or by some statute other than the admimistrative procedure act itself. ${ }^{53}$

The technique employed by these administrative procedure acts has been widely followed, with unfortunate results. Trial-type hearings are frequently required where they are unnecessary to achieve goals of accuracy, efficiency and acceptability. In many other instances such hearings are not required although a pragmatic analysis of the circumstances indicates that these goals could be better served by a trial-type hearing without undue

purpose of promulgating policy-type rules or standards, on the one hand, and proceedings designed to adjudicate disputed facts in particular cases on the other.

United States v. Florida E. Coast Ry., 410 U.S. 224, 245 (1973). The words from Justice Rehnquist's majority opinion quoted above bear comparison with words from another era, in this case those of Justice Frankfurter, conceding that his judicial formula provided no litmus test:

We are aware that to give the examiner's findings less finality than a master's and yet entitle them to consideration in striking the account, is to introduce another and an unruly factor into the judgmatical process of review. But we ought not to fashion an exclusionary rule merely to reduce the number of imponderables to be considered by reviewing courts.

Universal Camera Corp. v. NLRB, 340 U.S. 474, 493 (1951).

50. "[E]very case of adjudication required by statute to be determined on the record after opportunity for agency hearing . . . ." 5 U.S.C. \& 554(a) (1970).

51. "[A] proceeding before an agency in which the legal rights, duties, or privileges of specific parties are required by law or constitutional right to be determined after an agency hearing." MOdel State AdMinistrative Procedure ACT § 1(3) (1946).

52. "[A] proceeding, including but not restricted to ratemaking, [price fixing], and licensing, in which the legal rights, duties, or privileges of a party are required by law to be determined by an agency after an opportunity for hearing," MODEL STATE ADMINISTRATIVE PROCEDURE ACT REVISED § 1(2) (1961).

53. No matter how "circumstantial" or "adjudicative" the facts, and no matter how selective in application the exercise of agency power may be, the federal Administrative Procedure Act's trial-type hearing requirements do not apply in the absence of an independent statutory requirement for a hearing. Camp v. Pitts, 411 U.S. 138, 140-42 (1973). 
impairment of the efficiency of the administrative process. ${ }^{54}$ The problem is particularly nettlesome because of the relative inflexibility of the many administrative procedure acts which ordain a particular complex of adjudicative procedures and either apply them or do not. Hybrid procedures must be devised to accommodate the various conflicting interests in the administrative process. ${ }^{55}$

It must be emphasized that a statute which establishes the requirement of a hearing as a condition precedent to valid administrative action does not always reflect a measured legislative judgment in pursuit of the goals of accuracy, efficiency and acceptability. Experience suggests that the decision to require a hearing frequently results from political considerations or from partisan trade-offs within the political process itself. ${ }^{56}$ There may even be situations in which the particular legislation creating and establishing the agency imposes procedural safeguards more extensive than the trial-type hearings required by the applicable administrative procedure act. ${ }^{57}$ In any event, there appears to be a growing skepticism towards the assumption that the benefits of trial-type hearings will almost always outweigh the costs. This skepticism should provide the occasion for reexamining the question whether the traditional administrative procedure act methods for identifying the circumstances in which a trial-type hearing is appropriate are worth retaining. ${ }^{58}$

Legislative authorities should follow the lead of the judiciary by balancing the factors involved in determining the appropriateness of a hearing, and by attempting to fashion statutory procedures that fit the needs of individual administrative programs. In a series of recent decisions, the United States Supreme Court has already begun to generate an elaborate but flexible constitutional "code" of procedural requirements for administrative adjudications. ${ }^{59}$ This "code" should be carefully compared with the proce-

54. See note 67 infra. For a thoughtful and restrained appraisal of the current methodology of determining the propriety of a trial-type hearing in a particular instance, together with a modest proposal for reform, see Cramton, A Comment on Trial-Type Hearings in Nuclear Power Plant Siting, 58 VA. L. REv. 585 (1972).

55. See note 61 infra.

56. The role of special interest groups in winning legislative impositions of trial-type hearings as conditions to the exercise of agency authority is difficult to document. However, little doubt exists as to the refined implementation of such tactics by powerful groups interested in slowing, blocking or blunting unwanted regulation. See, e.g., Hamilton, supra note 40, at 1288.

57. For some classic examples, see Hamilton, Rulemaking on a Record by the Food and Drug Administration, 50 TEx. L. REv. 1132 (1972), and the statutes cited at note 40 supra.

58. See Boyer, Alternatives to Administrative Trial-Type Hearings for Resolving Complex Scientific, Economic, and Social Issues, 71 MICH. L. REV. 111 (1972).

59. The Supreme Court decisions which can be said, collectively, to establish a constitutionally derived "code" of administrative procedure are conveniently identified in a useful footnote in Mashaw 28 n.1. See also Comment, Procedural Due Process after Goss v. Lopez, 1976 DUKE L.J. 409. 
dures imposed by statutes and the criteria employed by those statutes for identifying the types of proceedings to which these procedural requirements are applicable. Such a comparison may well indicate that the "code" which courts have been articulating on a case-by-case basis, although not as precise as administrative procedure acts in identifying the procedural requirements imposed or the proceedings in which the safeguards must be observed, is nevertheless a more realistic and practical basis for accommodating the goals of accuracy and acceptability with the increasingly significant goal of efficiency. ${ }^{60}$ In stronger terms, the question may be asked whether this remarkable body of case law applicable to administrative adjudication has not made the analogous provisions of the various administrative procedure acts obsolete. ${ }^{61}$

Another possible method for identifying the circumstances in which a trial-type hearing may be required is suggested by the recently enacted Florida Administrative Procedure Act. ${ }^{62}$ The Florida approach may, for lack of a better term, be described as the "self-certification" technique. The Florida Act distinguishes between formal and informal hearings and limits the former to those cases in which a disputed issue of material fact is involved. ${ }^{63}$ Whether formal or informal, a hearing is required only if a "substantial interest" of a party is affected. ${ }^{64}$ The Act purports to determine, on its own and without reference to other statutes, whether a hearing is mandatory and, if so, the type of proceeding required. ${ }^{65}$ In other words, it establishes a general framework which can be used to determine what hearing procedures are required in any particular situation. The Act also brings a great deal of flexibility to administrative adjudication. Because it permits a hearing to be converted from formal to informal after a proceeding has been in progress for some time, ${ }^{66}$ some procedural issues can be left until the presiding officer is fully acquainted with the issues and interests

60. See generally Cramton, supra note 54 .

61. A number of opinions in recent years have noted that the polar choices imposed by the federal Administrative Procedure Act are not a satisfactory response to many of the pragmatic requirements of complex and sophisticated regulatory programs. See, e.g., United States v. Florida E. Coast Ry., 410 U.S. 224, 238 (1973), clearly holding that while a particular administrative proceeding might not be subject to the provisions of 5 U.S.C. $\$ \S 556$ and 557 (1970) because of the absence of the magic words "on the record," the circumstances might otherwise require elements of a trial-type hearing above and beyond those required by the simple "notice and comment" procedure mandated by 5 U.S.C. $\$ 553$ (1970). See also United States v. Allegheny-Ludlum Steel Corp., 406 U.S. 742, 757 (1972); Mobil Oil Corp. v. FPC, 483 F.2d 1238 (D.C. Cir. 1973).

62. Fla. Stat. ANn. $\S 120.50-.73$ (West Supp. 1977).

63. Id. § 120.57 .

64. Id.

65. Id. $\S \S 120.57(1)(\mathrm{b})(1), .57(2)(\mathrm{a})(2) ;$ see Levinson, supra note 32 , at 666-68.

66. Levinson, supra note 32 , at 666 n.284. 
involved, and procedures can be modified so that foundations for procedural challenges on appeal can be avoided.

By determining both the requirement of a hearing and the quality of the procedure on an ad hoc basis (depending upon whether a "substantial interest" of a party is involved and whether there is a "disputed issue of fact'), the Florida Act may simply reflect already recognized constitutional requirements. In any event, it constitutes a marked departure from conventional methods for resolving this question, and its effectiveness should be a matter for close and continuing study.

The legal community must attempt to identify the type of administrative proceedings for which trial-type procedures are appropriate and the particular procedures that are needed in individual contexts. Permitting such questions to turn on the sterile inquiry whether there is legislation calling for a "hearing" has undoubtedly resulted in poor decisions. Trial-type procedures are frequently required when they are inappropriate and omitted when they are needed. ${ }^{67}$ Fair and efficient operation of the administrative process demands the development of a richer conceptual framework for discussing the appropriateness of various hearing-type procedures and concomitant legislative reform.

\section{SELECTION OF A PRESIDING OfFICER}

There is a second important reason to develop a better understanding of administrative hearings: it is difficult even to begin to discuss the role of the administrative law judge unless the hearing over which he will preside is fully understood. At the present time, the only situation in which it can be

67. Forceful and persuasive arguments have been made against the use of trial-type hearings in federal rule-making proceedings, where such hearings are required simply because independent statutes call for hearings on the record. See Hamilton, supra note 40; Hamilton, supra note 57; Westwood, Administrative Proceedings: Techniques of Presiding, 50 A.B.A.J. 659 (1964). On the other hand, disputes arising in connection with applications for federal bank charters are not independently subjected to hearing requirements so that the trial-type procedures of the federal Administrative Procedure Act do not apply. Camp v. Pitts, 411 U.S. 138, $140-41$ (1973). Yet it has been argued with equal force that the character of the factual disputes and the nature of the interests involved in bank charter applications are conspicuously appropriate for at least some of the procedural protections commonly associated with trial-type hearings. Indeed, a resolution recently adopted by the Council of the Section of Administrative Law of the American Bar Association recommends that the Association's House of Delegates endorse the proposition that de novo bank chartering proceedings be subject to the trial-type hearing requirements of 5 U.S.C. $\$$ 556-557 (1970). SECTION OF ADMINISTRATIVE LAW, ABA, Minutes of the Annual MeEtings of the Council and Section 14-23 (Aug. 7-11, 1976), reproduced in 13 SECTION OF ADMINISTRATIVE LAW, ABA, ANNUAL REPORTS OF COMMITTEES 281-90 (1976). See also Scott, In Quest of Reason: The Licensing Decisions of the Federal Banking Agencies, 42 U.CHI. L. REv. 235, 290 (1975). Professor Scott is dubious about the need for trial-type hearings, but clearly indicates that the wind is blowing in the direction of more structured and open decision-making in the chartering function with safeguards to assure those affected that discretion is being exercised fairly and rationally. 
said that the presence of an independent hearing officer is absolutely required is where a statutory provision explicitly calls for such an officer. In its decade-long development of a constitutionally required minimum administrative due process code, the United States Supreme Court has occasionally referred to the requirement of an independent decisional authority, ${ }^{68}$ but it has so far declined to spell out either the professional qualifications or any selection constraints constitutionally applicable to them, other than freedom from disabling bias. In order to begin to fill this void, the following discussion attempts a comparison of the various methods currently being employed for the selection of presiding officers in those cases where their function is mandated by statute. The same policy considerations are also relevant in deciding, when there is no such legislative command, whether a presiding officer is required by any constitutionally inferred "rudimentary due process" and, if so, the nature of that officer's credentials and the degree of his independence.

Assuming that a class of proceedings can be identified in which judge-like presiding officers are required by statute, it is obvious that the federal system of providing independently certified ALJs, who then (although retaining a theoretical independence) become more or less permanently associated with the agency for which they conduct hearings, is not the only method. Although the federal approach has been followed in a number of states, ${ }^{69}$ it does have several disadvantages.

The most significant difficulty with the federal approach is that the ALJ's experiences are typically confined to recurring types of disputes common to the agency for which he works. At the $\mathrm{CAB}$, he is concerned with such things as route certifications; at the NLRB, with unfair labor practice disputes. This state of affairs is widely thought to give the ALJ an expertise which contributes to the efficiency of the administrative process. However, such forced specialization ignores the original reasons for creation of the position of ALJ-impartiality, objectivity and independence appear to have been stronger considerations than that of expertise. ${ }^{70}$ Former American Bar Association President Bernard G. Segal has put it this way:

The most persistent argument against unification is that an administrative law judge must be expert in the substantive law of the agency. I am

68. "And, of course, an impartial decision maker is essential . . . . We agree with the District Court that prior involvement in some aspects of a case will not necessarily bar a welfare official from acting as a decision maker. He should not, however, have participated in making the determination under review." Goldberg v. Kelly, 397 U.S. 254, 271 (1970). See also Withrow v. Larkin, 421 U.S. 35, 46-55 (1975); Wolff v. McDonnell, 418 U.S. 539, 566-70 (1974); Gibson v. Berryhill, 411 U.S. 564, 578-79 (1973).

69. See notes $28-29$ supra and accompanying text.

70. See, e.g., COMMITTEE ON AdMINISTRATIVE Procedure, supra note 15, at 45-50; Hoover COMMISSION REPORT 88-93; HOOVER COMMISSION TASK FORCE REPORT 257-69. 
no more persuaded by this thesis than I am that we need to have specialized judges in our federal court system. I realize that administrative law judges function in very specialized areas of the law, but so do federal district judges, and yet they have demonstrated no ineptitude in making findings and reaching conclusions in the most technical disciplines. Like the district judge in a nonjury trial, administrative law judges are largely finders of facts. They are not "special masters," advisers, or counselors. Their function is to judge, after hearing counsel and the testimony and doing the necessary analyzing, weighing, and studying, casse by case, issue by issue. To the extent that impartial, technical advice or instruction might be desirable, this could be provided by a cadre of experts to be available to administrative law judges generally. ${ }^{71}$

In addition to the fact that the ALJ position was not designed with an eye toward special expertise, specialization may put a presiding officer at a distinct disadvantage in the discharge of his function as a fact-finder. ${ }^{72}$ As an eminent jurist observed, "One of the dangers of extraordinary experience is that those who have it may fall into the grooves created by their own expertness." "73 Fact-finders with great expertise in a particular area may have such strong preconceptions about certain problems that they will not be able to evaluate evidence or arguments before them fairly or accurately.

To the extent that efforts are directed at insuring a presiding officer who is fair, objective and free from institutionally acquired biases, the present system of permanent assignment of ALJs to particular agencies seems distinctly counterproductive. The current federal approach encourages a closed-circuit system which may well deprive agencies of mature and competent ALJs while at the same time creating at least the appearance of bias in favor of the agency. ${ }^{74}$ This system has been described as one of

71. Segal, The Administrative Law Judge: Thirty Years of Progress and the Road Ahead, 62 A.B.A.J. 1424, 1424-25 (1976).

72. An early recognition and discussion of the value of rotating ALJs between agencies so that capacities for judgment would be sharpened by exposure to a greater diversity of disputes can be found in Macy, The APA and the Hearing Examiner: Products of a Viable Political Society, 27 FED. B.J. 351, 388-93 (1967); cf. Zwerdling, Reflections on the Role of an Administrative Law Judge, 25 AD. L. REV. 9, 38-39 (1973). For a discussion of the shortcomings of expertise and an argument that specialization has been "oversold" in the United States, see Schwartz, Legal Restriction of Competition in Regulated Industries: An Abdication of Judicial Responsiblity, 67 HARv. L. REv. 436, 471-75 (1954). See also What the Justices Are Saying, 62 A.B.A.J. 1454, 1456 (1976):

Justice Powell: "My brothers gently rejected my proposal [for a staff of experts] reminding me that I was being paid to render personal judgments, even if they were devoid of expertise"; Justice Rehnquist: "Somewhere there comes a tipping point ... at which the number of routine and uninteresting tasks . . . becomes so largc a portion of the whole that the number of qualified people willing to take the job diminishes sharply."

73. United States v. United Shoe Mach. Corp., 110 F. Supp. 295, 346 (D. Mass. 1953) (Wyzanski, J.).

74. Segal, supra note 71, at 1426; Miller, The Education and Development of Administra- 
"selective certification,"75 although that term does not clearly describe all that is involved in the process. Under the present system, the Civil Service Commission subjects applicants for positions as administrative law judges to examinations and interviews. Persons who meet the requirements are then "certified" and placed on a "register" which is supplied to an agency on request. ${ }^{76}$ Although cumbersome and exacting, the Civil Service Commission's standards are relatively neutral. Under the system of selective certification, however, the agencies are permitted to impose their own qualifications, in addition to those employed by the Civil Service Commission, as conditions for appointment as an ALJ. These agency qualifications typically take the form of a requirement that the applicant have two years of recent experience in the field of administrative law, or, occasionally, that the applicant be familiar with the substantive administrative law of the agency by which he or she is to be employed. ${ }^{77}$

The result of the selective certification process is to give attorneys on the staffs of particular federal agencies a decided advantage over other applicants. At one time it was pointed out that as a result of this selective certification process, over two-thirds of the NLRB ALJs were former employees of the Board, and fifty percent of the ICC ALJs had in fact been employed by the Commission at the time of their appointment. ${ }^{78}$

In addition to the possibility of depriving the agency of the most competent candidates for their ALJ openings, selective certification creates an unhealthy appearance of institutional bias. As Bernard Segal has pointed out, "The permanent assignment of an administrative law judge to a single agency . . . tends to produce an inbreeding, which in turn contributes even more to the appearance of bias. For example, of the thirteen administrative law judges assigned to the Federal Trade Commission, twelve are former employees of that commission." "79

A different approach from the federal system is taken by both California and Florida. At least as regards those agencies which are required to

tive Law Judges, 25 AD. L. REv. 1, 3 (1973). "The defects of selective certification rot the entire recruitment and appointment process . . . [T] hey undermine confidence in the administrative process . . . " 6 Section of Administrative LAW, ABA, ANNUAL RePorts of COMmitTEes 20 (1969).

75. See Miller, The Vice of Selective Certification in the Appointment of Hearing Examiners, 20 AD. L. REv. 477 (1968).

76. B. SCHWARTZ, supra note 14 , at 293-94.

77. Miller, supra note 75 , at 483 .

78. Id. 480.

79. Segal, supra note 71, at 1426 . The related ethical problems posed by the "migration" of attorneys between federal agency staffs and private law firms representing clients before those same agencies, and some of the solutions currently under consideration, are discussed in Note, Ethical Problems for the Law Firm of a Former Government Attorney: Firm or Individual Disqualification?, 1977 DUKE L.J. 512. 
utilize independent hearing officers, those officers are supplied by a central agency and are neither employed by nor permanently assigned to the agency for which they conduct hearings. ${ }^{80}$ At the federal level, the movement towards the creation of an independent corps of administrative law judges represents a trend in the direction of the approaches already taken. by California and Florida. ${ }^{81}$

A third approach takes the agency out of the adjudication business altogether. This result can be achieved by withdrawing the power of an agency to reject, revise or modify the ALJ's decision; in other words, to make the decision of the ALJ the "final word" of the agency. Another method of accomplishing the same objective is simply to establish an Administrative Court, independent from the agency and exercising full power of adjudication over disputes between the private sector and the agency. ${ }^{82}$

Something akin to this third approach was recently adopted in Missouri when that state created an Administrative Hearings Commission with jurisdiction over disputes between various professional licensing boards and those who are subject to such licensing. ${ }^{83}$ With respect to proceedings charging an existing licensee with misconduct, the Commission is empowered only to make recommendations to the licensing agency; ${ }^{84}$ with respect to a refusal to license, however, the Commission is empowered to issue an "order." 85 At the present time, legislation is pending before the Missouri General Assembly which would significantly enlarge the jurisdiction of the Administrative Hearing Commission to encompass vast new areas of state licensing functions including those now exercised by the Health Division of the Department of Social Services, as well as all tax disputes (other than

80. Cal. Gov't Code AnN. $\S \S 11370.1-.3$ (West Supp. 1977); Fla. Stat. AnN. $§ 120.65$ (West Supp. 1977).

81. At the federal level, the idea of an "independent corps" goes back at least as far as 1941, when an offieial proposal was made for a modest interchange between agencies. CoMmITTEE ON ADMINISTRATIVE PROCEDURE, supra note 15, at 49. A limited version of this concept was later endorsed by the then-Chairman of the United States Civil Service Commission. Macy, supra note 72 , at 388-92. Only recently, however, has it been forcefully proposed that the system adopted in Califormia and Florida be accepted at the federal level. See Segal, supra note 71.

82. See Hoover COMmission RePORT 87-88; HoOver Commission TASK FORCE Report 246. The literature on the proposal to establish an Administrative Court is extensive. An especially thorough and thoughtful study is Fuchs, The Hoover Commission and Task Force Reports on Legal Services and Procedure, 31 IND. L.J. 1, 16-22 (1955).

83. Mo. ANN. Stat. § 161.252 (Vernon Supp. 1977). See also Special Project, supra note 37. See notes $35-37$ supra and accompanying text.

84. "The commission may make recommendations as to appropriate disciplinary action but any such recommendations shall not be binding upon the agency." MO. ANN. STAT. $\$ 161.292$ (Vernon Supp. 1977).

85. "[T]he administrative hearing commission shall issue an appropriate order to accomplish such examination or licensure or renewal, as the case may be." Id. § 161.302. 
property valuation and assessment) with the Department of Revenue. ${ }^{86}$ The legislation would also authorize expansion of the number of commissioners from the single commissioner presently allowed, ${ }^{87}$ and would permit the commissioners to sit in panels. ${ }^{88}$

The effect of the Missouri reforms would be to identify the particular classes of disputes (licensing and taxation) which are highly selective as to the individual affected, which touch interests to which our legal system has traditionally given careful protection, and which typically involve circumstantial or adjudicative facts. The Missouri reforms would take these disputes out of the agencies (where they are presently adjudicated, on the record, before an agency hearing examiner) and transfer them to an independent hearing commission which in many ways would exercise the functions of an administrative court. Whenever a dispute within those areas became a "contested case" so that a trial-type hearing on the record was required, it would no longer be subject to administrative adjudication by the department or division involved; such controversies would be heard by the Administrative Hearing Commission.

It is important to emphasize that the Missouri reforms do not limit the powers of the licensing agencies or the Department of Revenue to negotiate informally with persons subject to their jurisdiction, nor is discretion necessarily limited. The reforms would merely subject a large class of disputes for which trial-type hearings are statutorily required to the jurisdiction of an adjudicative authority, the Administrative Hearing Commission, which is totally independent from the agency or department with whom the objector is having a dispute.

The Missouri reforms, whether consciously or otherwise, reflect one of the more controversial proposals of the so-called Second Hoover Commission, which concluded that experience with the administrative process had reached a point where it was expedient to transfer jurisdiction over certain recurring types of disputes to an Administrative Court. ${ }^{89}$ The Missouri Administrative Hearing Commission can make only non-binding "recom-

86. S. 106, 79th Gen. Ass. of the State of Missouri, 1st Reg. Sess. $\$ \S 190.171-198.430$, 202.915, 311.680-.691 (1977). The foregoing provisions confer jurisdiction over the licensing activities of the Division of Health, the Department of Mental Health and the Supervisor of Liquor Control on the Administrative Hearing Commission. Jurisdiction over revenue disputes would be conferred by id. $\S$ 136.245-.310, 142.080-149.035.

87. See note 35 supra and accompanying text.

88. S. 106,79 th Gen. Ass. of the State of Missouri, 1st Reg. Sess. $§ 161.252$ (1977).

89. See HOOVER COMmission RePORT 84-88; HOOVER COMMISSION TASK FORCE REPORT 246-50. Although the final report recommended such a transfer of jurisdiction for trade, taxation and labor disputes, the Task Force Report had only called for the transfer of trade and taxation matters. Compare HOOVER COMMISSION REPORT 87-88 with HOOVER COMMISSION TASK FORCE REPORT 246. 
mendations" with respect to misconduct of which it finds licensees guilty. ${ }^{90}$ But in all other respects, such as the ordering of licensure or examination, ${ }^{91}$ its decisions achieve the finality envisioned by members of the Hoover Commission and its Task Force, who believed that in certain areas experience justified a transfer of decision-making authority to an Administrative Court. ${ }^{92}$

\section{THE NEED FOR REFORM}

The widely followed federal system uses statutory referents to identify proceedings which require a presiding officer. ${ }^{93}$ While assigned to the agency, the federal presiding officer (ALJ) is independently certified and has his or her level of compensation established by the Civil Service Commission. ${ }^{94}$ The federal approach seems to have three major drawbacks, however. Two of them have already been discussed. The first involves the absence of perspectives and enhanced capacity for analogy which is arguably a consequence of the so-called "specialization" encouraged by the present system. ${ }^{95}$ The second disadvantage is the system's amenability to processes of selective certification, which may eliminate highly qualified persons for the ALJ eligibility lists and may create appearances of partiality. ${ }^{96}$

\section{The Problem of Finality}

A third problem with the federal approach has received little attention. It involves the possible frustration or rejection of a judicial-type decision on policy or political grounds by agency members who do not necessarily have the judicial competence of the ALJ. ${ }^{97}$ It may well be that the effective implementation of policy requires that final adjudicatory responsibility be vested in the agency itself or the appropriate cabinet member; it may even be that this is technically a requirement of the Constitution..$^{98}$ Nevertheless, the fact remains that under the present system the decision of an ALJ, reached after a trial-type hearing which includes many, if not most, of the proce-

90. See note 84 supra.

91. See Mo. ANN. Stat. $\$ 161.302$ (Vernon Supp. 1977).

92. See note 105 infra and accompanying text.

93. See note 50 and text accompanying note 53 supra.

94. 5 U.S.C. \$ 5362 (1970); see Zwerdling, supra note 72, at 12-14. See generally B. SCHWARTZ, supra note $14, \S 103$.

95. See notes 70-73 supra and accompanying text.

96. See notes 74-79 supra and accompanying text.

97. See Lorch, Administrative Court via the Independent Hearing Officer, 51 JUDICATURE 114 (1967).

98. The full "separation of powers" implications of Buckley v. Valeo, 424 U.S. 1 (1976), are yet to be determined. See generally Note, Congressional Veto of Administrative Action: The Probable Response to a Constitutional Challenge, 1976 DUKE L.J. 285. 
dures common to the judicial process, may nevertheless be rejected or modified by an "appellate" body which does not have a judicial composition.

It is noteworthy that the current proposals for establishing an independent corps of administrative law judges within the federal system would overcome only two of the three drawbacks mentioned above. ${ }^{99}$ An independent corps of ALJs moving relatively freely among agencies would develop the background and breadth which some critics claim the present system discourages. Since no ALJ in an independent corps would be assigned to any particular agency, the selective certification abuse would likewise automatically disappear. Nevertheless, under an independent corps system the ALJ's decision would still, in most cases, be subject to agency rejection or revision.

It is with the last of the three drawbacks that the Hoover Commission recommendations and, in certain areas at least, the Missouri reforms would deal. Once a dispute has been the subject of a trial-type hearing before an administrative tribunal which is independent of the particular governmental entity involved in the dispute, it should be reviewable only in an Article III court and not subject to executive revision or rejection. ${ }^{100}$ Current proposals for the creation of an independent corps of administrative law judges at the federal level do not so provide, and this common deficiency must be remedied if the advantages of finality in administrative adjudication are to be fully realized. ${ }^{101}$

Among other manifestations of the accelerating judicialization of the administrative process, one can discern a tendency to give the decisions of presiding officers increased dignity and weight. ${ }^{102}$ In many instances, the decision of the federal ALJ now becomes the decision of the agency ". . . unless there is an appeal to, or review on motion of, the agency within time provided by rule." 103 Paralleling this development have been noticeable trends towards an upgrading of qualifications for presiding officers so that today, at least at the federal level, many of these persons are truly judges whose decisions may be as carefully reasoned and based upon proof adductions as elaborate as those of an ordinary judicial proceeding. ${ }^{104}$ In light of

99. Compare Segal, supra note 71 with Lorch, supra note 97.

100. See President's Advisory Council on Executive Organization, A New RegulaTORY FRAMEWORK: REPORT ON SELECTED INDEPENDENT REgUlatORY AGENCIES 49-50 (1971); Lorch, supra note 97, at 116-17.

101. PRESIDENT'S ADVISORY COUNCIL REPORT, supra note 100.

102. Macy, supra note 72 , at $380-88$; Schotland, supra note 3 , at $268-70$.

103. 5 U.S.C. $\$ 557($ b) (1970).

104. See Gillilland, The Certiorari-Type Review, 26 AD. L. REv. 53 (1974) (arguing that the experience and talents of the ALJs justify the Civil Aeronautics Board's policy of giving the ALJ's decision final effect unless reviewed on motion of the Board); Segal, supra note 71; Zwerdling, supra note 72. 
all this it may be appropriate to consider whether there are areas where the agency itself should not engage in adjudication, leaving such matters to an independent body. The words of the Hoover Commission Task Force may have been more prophetic in this respect than was first realized:

When agencies are established to explore a new area of regulation, it is expedient to combine in them all the powers which are needed to achieve maximum effectiveness, even at the cost of consolidating judicial and legislative functions. Subsequently, it may be feasible to transfer certain primarily judicial functions to the courts.

The application of judicial remedies by the executive branch need not be surrendered in the first instance to courts of general jurisdiction. The new function may warrant a new court. ${ }^{105}$

In Missouri, at least as far as licensing is concerned, that "new court" is the Administrative Hearing Commission, and, under legislation presently proposed, its jurisdiction stands to be expanded significantly. ${ }^{106}$ At the federal level, there is discernible movement in the same direction, though it is not yet completed in any particular area. However, the increased dignity being accorded the office of the ALJ, the proposals presently being submitted for the creation of an independent corps of ALJs, and the enhanced weight being given to ALJ decisions under the federal Administrative Procedure Act combine to signal a development towards giving the ALJ the final decision, at least in certain areas of adjudication. If and when that point is reached, we will have the Hoover Commission's "Administrative Court." 107

105. HOOver COMmission TASK FORCE REPORT 241.

106. See note 86 supra and accompanying text.

107. See Lorch, supra note 97; cf. PRESIDENT's ADVISORY COUNCIL, supra note 100, at 47-58 (1971); Caldwell, A Federal Administrative Court, 84 U. PA. L. REv. 966 (1936); Lorch, The Federal Administrative Court Idea, 52 A.B.A.J. 635 (1966). 